\title{
Medical History
}

\section{Osler and the Canadians in Folkestone}

\author{
BRIAN LEWIS
}

British Medical fournal, 1976, 2, 1545-1548

28 June 1914 was a glorious summer day in Folkestone. The Leas, perhaps the most beautiful promenade in England, overlooked the twinkling blue English Channel, and out of a cloudless sky the sun blazed down on the well-to-do as they strolled between the Hotel Metropole and the Grand Hotel. The Boer War was but a memory. King George $V$ sat on the throne, albeit the architecture of the town was more characteristically in the Edwardian style, associated with his late father.

If the strollers thought at all about Canada it might well have been some stirring tale of that young Dominion published in the Boy's Own Paper, and those who thought of Ireland would have associated it with Home Rule Bills and sighed gently at the failure of $\mathrm{Mr}$ Gladstone to solve this perennial problem.

Who would blame them if they did not realise that that afternoon Archduke Franz Ferdinand and his wife, the Countess Sophie Chotek, were celebrating their 14th wedding anniversary by inspecting the Austro-Hungarian army in Bosnia at its capital, Sarajevo. Nor could they expect that a 19-year-old schoolboy, Gavrilo Prinzip, was going to step on to the running-board of the royal car, killing the Archduke with one shot and his wife sitting in the back with a second. Yet, on that glorious June afternoon, 62 years ago, the fuse of the greatest battle in history was lit.

\section{Folkestone, summer 1914}

At the Royal Victoria Hospital, Folkestone, built in 1889 , Dr Linnington and Dr Tyson were discussing a case with $\mathrm{Dr}$ Eastes who had charge of their new $x$-ray department. The staffroom looked out over Radnor Park, where nursemaids wheeled their prams on the shady side of the walk. Folkestone was also served by one or two nursing homes, such as the St Andrews Convalescent Home, but these were more for the care of elderly gentle ladies, and the only other acute hospital was the Shornecliffe Military Hospital at the Barracks, named after Sir John Moore, whose body had been buried at Corunna. Shornecliffe Camp now had spacious brick-built accommodation for some 5000 troops, since the wooden structures erected for troops leaving for the Crimea had been dismantled.

Miss Browne, the matron of the Royal Victoria, together with Sisters Lawson and McBeth, had little in the way of staff problems, and indeed any shortages that did exist were filled by the Folkestone and Sandgate St John Ambulance Brigade, whose Commandant was Mr F A Adams, and whose corps surgeon some 60 years later I have the honour to be.

If you had suggested to these ladies and gentlemen that

Based on an address given at the BMA/CMA/IMA meeting in Dublin on 2 July 1976.

Royal Victoria Hospital, Folkestone, Kent

BRIAN LEWIS, MB, FFARCS, consultant anaesthetist during the next four years they were to see and treat patients from every corner of the earth, and that their town would have no fewer than 47 hospitals within its organisation, they would, I think, have politely assumed that you had taken leave of your senses.

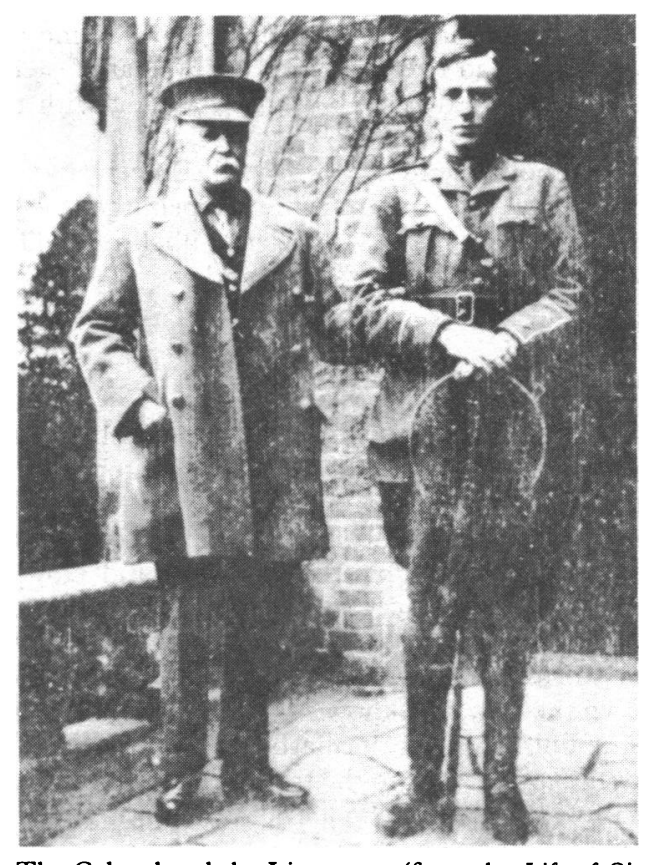

The Colonel and the Lieutenant (from the Life of Sir William Osler, Vol II, Cushing).

Nor, I suspect, would Sir Arthur Markham MP and his wife, enjoying their tea in their beautiful home Beechborough Park, have credited that it would by October be known as the Queen's Canadian Military Hospital, operated and maintained by the Canadian War Contingents Association, initially with 55 beds and a new operating theatre - or that four new wards would be erected in his grounds, the surgeon in chief being $\mathrm{Lt}$ Col Donald Amour, CMG, and the physician in charge Lt Col Sir William Osler, Bart MD.

Certainly in the succeeding weeks The Times carried news from its foreign correspondents indicating that all was far from well. But the general feeling of the population of Folkestone was that no one could challenge the might of the British Empire, and that even if they were so foolish as to try "it would be all over by Christmas." Britannia ruled the waves, and there before the eyes of everyone in Folkestone were the eight battleships of the first battle squadron, anchored off the Leas on a courtesy visit to the town. The date was 11 July 1914, and the mayor entertained Vice-Admiral Sir Lewis Bayly and 50 officers to a banquet at the Metropole Hotel. Afterwards they went out on to the Leas and stood to watch the armada illuminated. They were alongside 


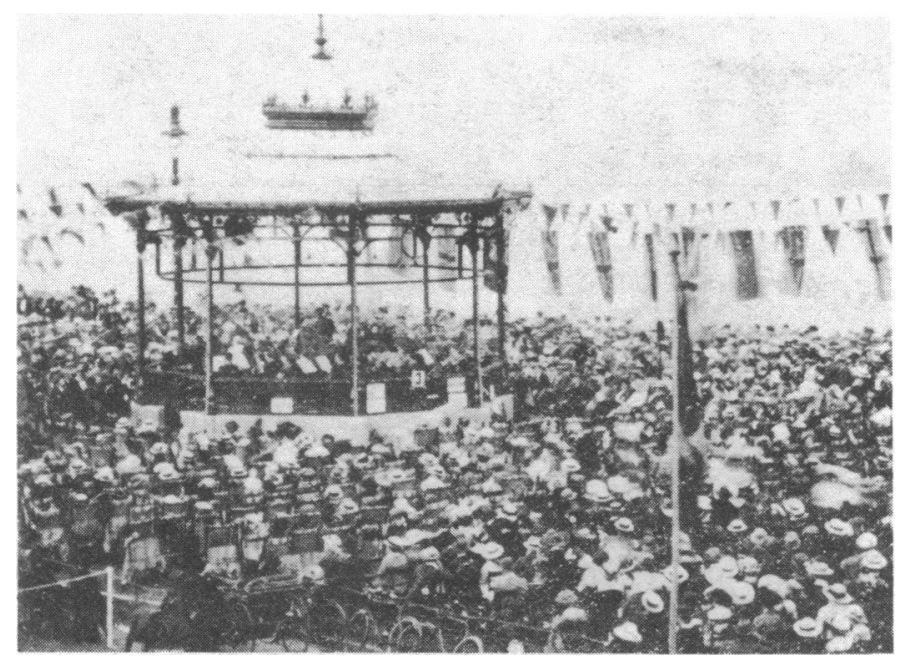

Season Band opening night, on Leas, July 1914.

the statue of William Harvey, Folkestone's most famous medical son, whose oration had been given by Sir William Osler in 1906, and to which he referred at the Toronto meeting with the BMA of that year.

Yet within a month sentence of death had been signed, sealed, and delivered upon the Empire of the Hapsburgs, the Russia of the Czar, and the Germany of Kaiser Wilhelm II. The end of the world of Queen Victoria was at hand.

\section{Folkestone's importance in the war}

I must explain why Folkestone became so important in the medical history of the first world war. A landslip had blocked the railway line between Folkestone and Dover, and the authorities had very shrewdly decided not to clear it but to use Folkestone as the Channel port for embarking troops, and Dover for the activities of the Royal Navy, and in particular the Dover Patrol. The railway workings which ran through the tunnel could thus be used for storing shells serving the great batteries.

Thus down the hill, now known as the Road of Remembrance, leading from Folkestone to its harbour, some ten million men were to march on their way to the front. The long Army tradition of Shornecliffe and at the School of Musketry at Hythe ensured that there were already considerable Army encampments available, and, as the visitors that had filled the area as holidaymakers returned home (away from the risk of shelling or bombing by the enemy's Gotha aeroplanes and zeppelins) there was a considerable amount of hotel accommodation that could be requisitioned for the reception of troops and of refugees. The first wave of the latter came from Belgium on 20 August 1914, when a fleet of boats entered the harbour bringing cargoes of huddled humanity with little more than the clothes they stood up in.

\section{The Canadians}

Canada was among the very first to respond to the call of England and her need. Within seven weeks of the outbreak of hostilities Canada created an army that ranked second to none in spirit and courage. This was not the first time that she had supported the mother country in her history: Canada had sent a force to India in the days of the Munity and in the South African war over 7000 Canadian troops had served with the British. What is so significant is that, unlike so many of the other participants, Canada had nothing to gain in material things; for her there was no question of territorial increase, no neighbouring lands that could become new parts of the Empire, and fall under her influence. She was not threatened by alien races, she had complete self-government, and could not look for greater partnership in managing her own affairs. Thus, it was an intangible sentiment, something that could not be set down in figures or measured in miles, but was an infinitely more valuable asset than statistics could ever show.

From the camp at Valcartier among the Laurentian Mountains, a force of some 33000 men from Canada was sent to Europe within eight weeks of the declaration of war. Initially these went to Salisbury Plain, and from there to Folkestone. They were to save Calais and wrote the first page of one of the most glorious chapters in military history, culminating with taking Vimy Ridge. A somewhat puritanical Canadian visitor to Folkestone during the war commented to the mayor that Canadian troops on leave on the previous weekend painted the town red, and he suggested they had given the Dominion something to live down. The mayor replied that in his opinion they had painted Vimy Ridge red, and given the world something to live up to.

Shornecliffe Camp by February 1915 appeared to be a suburb of Toronto with 40000 Canadian men in training. A detachment could leave Shornecliffe early in the morning and be in the trenches by lunch time. The camp was extended through Sandgate to Hythe, Dibgate, and Otterpool. It is lovely in spring and summer, a district that is on the border of the Garden of England-pasture stretching away to the belt of hills, glorious in their green, and on the other side lies the sea. By Sandling Junction trenches had been dug, and there men learned to go over the top. They were visited by the King, who was warm in praise for the smartness of his Canadian troops; and Lord Kitchener of Khartoum, who lived at Broome Park, near Canterbury, was a regular visitor.

Dr John Macneil of Toronto organised special work with the YMCA, and the Rev Dr T T Shields of Jarvis Street, Toronto, was chaplain. The Old Alhambra Music Hall was operated by the Canadian Red Triangle, and General Sir Sam Hughes and General Sir Sam Steele and their staffs were among the leading Canadian officers in Folkestone. The first Canadian baseball match played in England took place at the cricket ground in May 1915, and was described in the Folkestone Herald as resembling our familiar game of rounders. They noted that baseball was less artistic than cricket, but it lacked nothing in excitement, especially when the spectators, following the curious transatlantic fashion, shouted advice at the players and did not hesitate to yell criticisms.

Indeed, so numerous were the Canadians in Folkestone that the Canadian Club for Women was founded in December 1915 to welcome the wives and relatives of the Canadian Expeditionery Force. It was affiliated to the Victoria League and 1400 Canadian ladies were registered there. This is all the more remarkable when one thinks of the problems of the transatlantic crossing in wartime. The efforts did not end there, however, as the Khaki

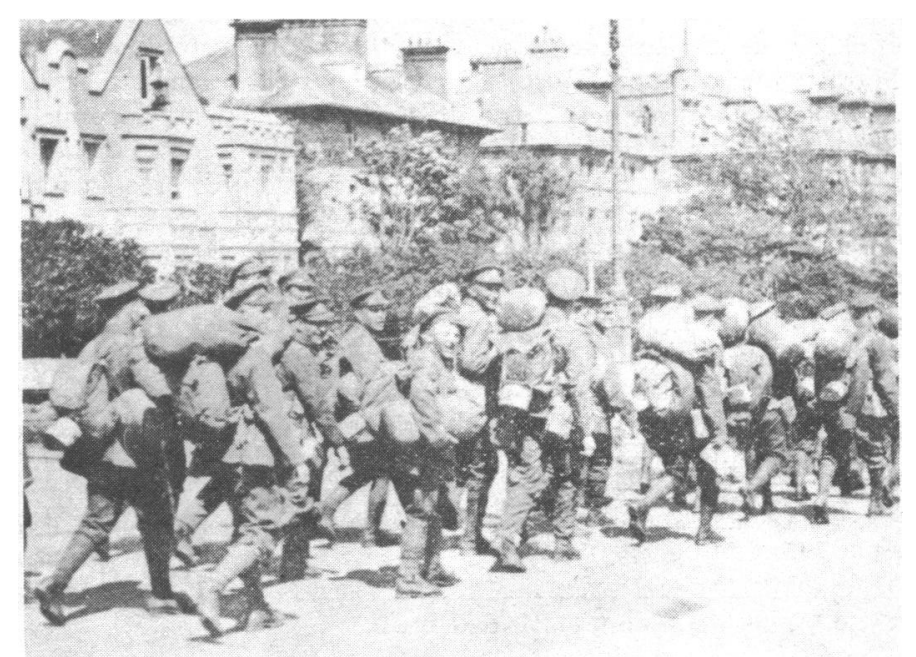

Soldiers marching from the Leas to embark for the front, Folkestone. 
University of Canada was formed by Principal Tory from Alberta University and Dean Adams of McGill, who took charge of the headquarters in London. A full programme was worked on, embracing as much of a university education as could be given in the Army.

\section{Sir William Osler}

Sir William Osler's relation with the Beechborough Park Hospital was a curious one, which was to continue until the end of the war. Not surprisingly as regius professor at Oxford, Osler had become attached in an honorary capacity to virtually every hospital that was treating Canadian troops throughout the hostilities-particularly the Duchess of Connaught Red Cross Hospital at Taplow, the Daughters of the Empire Hospital for Canadian Officers, the Canadian No 3 General Hospital (McGill Unit), and many others. Alas, in the summer of 1916 political rivalry between Liberals and Conservatives in Canada led to the replacement of the Director General of the Canadian Army Medical Corps by the Canadian Minister of Militia, who decided that dominion troops should be concentrated in special Canadian convalescent hospitals, since he felt they had been neglected in those run jointly.

This led to considerable complaint, and the matron at Taplow was dismissed. So outraged was Osler at what he described to Harvey Cushing as a Gilbertesque situation that he resigned from all hospitals under purely Canadian control until a separate and impartial committee of inquiry was set up under Sir William Babtie, which in all essential respects restored the status quo. As Beechborough Park, however, had been set up by the Queen it had remained under "imperial control" and, therefore, he remained on its staff. Thus, as the war continued, his connection with Folkestone grew.

Osler was a man of enormous principle: he would not tolerate injustice, and I think it is characteristic of him that he championed the inclusion of the names of German Rhodes Scholars at Oxford on the Roles of Honour of the colleges there. In the midst of patriotic fervour this was a far from popular thing to do, but it was typical of the man that in death as in life he would not distinguish between friend and foe.

Osler's involvement in the war was not just academic when one remembers that his only son, $L t$ Revere Osler, died of wounds on 30 August 1917 when " $A$ " Battery of the 59th Brigade was shelled near Langemark in Flanders. Harvey Cushing describes the burial as a strange scene: the great-great-grandson of Paul Revere wrapped in an Army blanket being buried under a British fiag in a Flanders oak grove. A simple cross inscribed Plot 4, row $\mathrm{F}$.

The transportation of patients to the hospitals was of keen interest to Osler since he had read the memoirs of the famous Baron Larrey, Napoleon's favourite surgeon, recounting the bitter experience of the Napoleonic Wars, particularly the

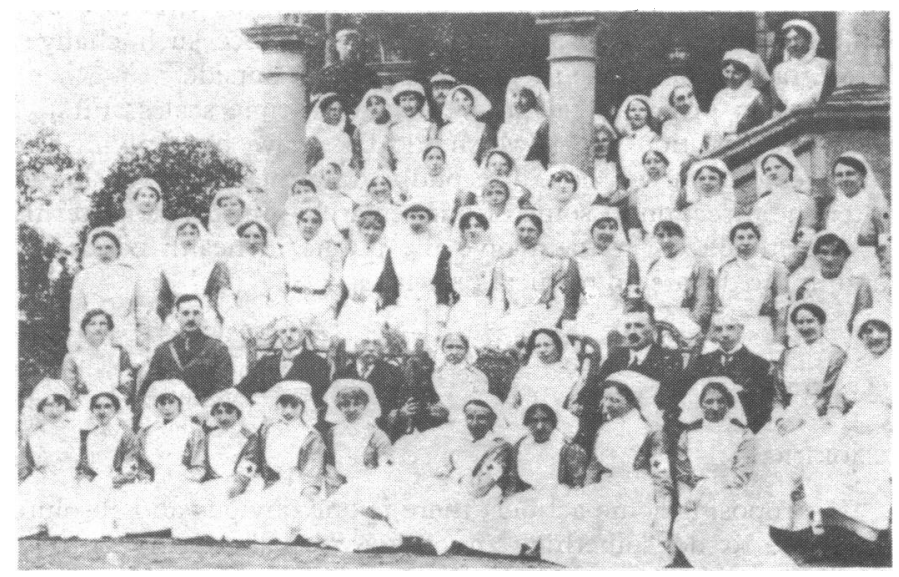

The Hon Florence Daly (Commandant), doctors, and nursing staff at Manor House Hospital, Folkestone.

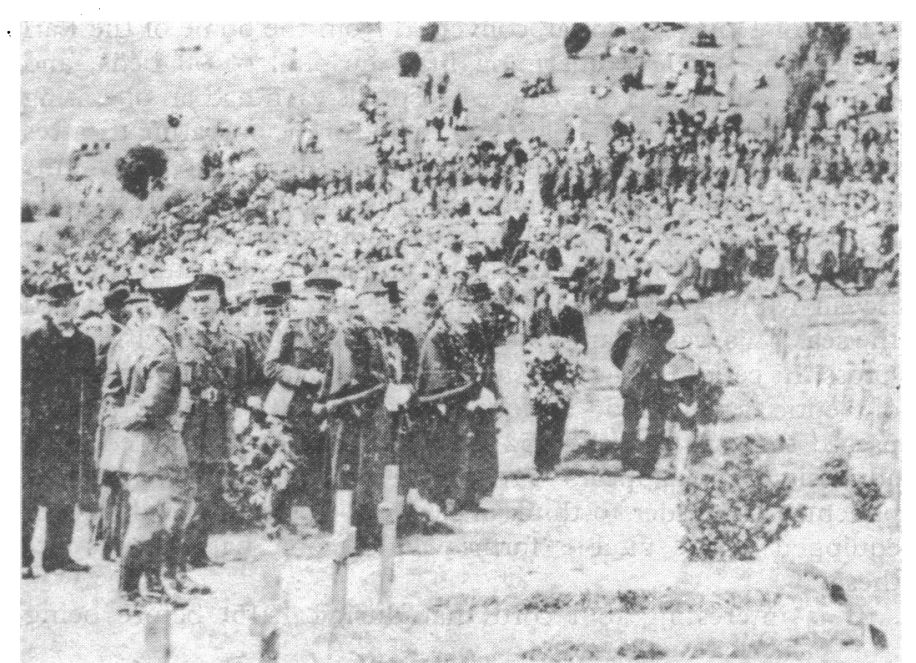

Canadian graves, Shorncliffe Cemetery.

Crimea, and of Osler's own studies of the American Civil War. Together with Lord Haldane and Sir Alfred Keogh he had spent a considerable time perfecting the organisation of the evacuation of wounded in the period before the war. Osler himself describes the evacuation from an ambulance train as it pulls up at the station-

"... fifteen big steel hospital carriages of the latest construction, presented by the United Millers' Association of Great Britain. Twentyeight motor ambulances are in attendance from the various hospitals, and the work of unloading begins. A more orderly, well-arranged business it is not possible to imagine. The cot cases are first lifted on their stretchers from the car and put in the ambulance-four in each, taking, as I timed it, a minute each. And all done so quietly, no talking, no fuss.

I went in the ambulance with the four men I had seen lifted out. Let us follow them to their beds. First an Irishman with a bullet wound in the scalp. "Begorra" said he, "I did not duck in time, but me mate's in Paradise today-a Saxon got him in the ear"; a Londoner with typhoid fever; a Lancashire lad with appendicitis; and a Cheshire man with a bad shrapnel wound in the leg.

By the way, all were smoking! They had been about six hours in the train, very comfortable and well fed; the wounded had been hit early in the morning. They reported that the only serious discomfort was getting to the dressing station. It took seven minutes in the ambulance to the hospital. The patients passed quickly through the admitting tent, where their tallies were copied and the ward assigned. The four were in bed and the two wounded had had their dressings changed, and all had had hot bouillon, in just 27 minutes from the time the first was lifted out of the ambulance train."

The speed with which hospital care could be instituted played an enormous part in the survival of the wounded. For example, of some 3000 patients passing through the Beechborough Park Hospital only 30 deaths are recorded. In an era in which anaesthesia was in its infancy and antibiotics unknown, I think this is an incredible tribute to the skill and devotion of those in every walk of life who cared for the wounded during this period.

\section{Folkestone hospitals}

Whatever the type of injury, Folkestone had a hospital catering for it. Thus the West Cliff Hospital with a staff of specialists from all over the Dominion, with the help of some of the most eminent of British doctors, performed wonders in patients with throat, eye, and ear illnesses and had a special department called the nose factory that performed miracles. In an early plastic surgery unit sketches were made of the lost feature, and noses were designed and built up with thin cuttings of bone. It was visited by the Duke of Connaught and the Canadian Prime Minister during the war. 
Manor House Hospital, converted from the home of the Earl of Radnor, made a charming little hospital of 90 beds, and Manor Court and York House Hospitals each had an operating theatre and another 100 patients. In one of the operating theatres out of a series of 180 major operations, there were only nine deaths. Doctors Streatfeild, Wainwright, and Wilgress were assisted by the inevitable Dr Lewis, showing that as usual the Welsh had got in on the act. One interesting hospital was the Bevan Military Hospital in Sandgate that actually overlooked the sea. This was organised by the Kent VAD of the British Red Cross. Its central court was entirely devoted to open air treatment of septic cases, and, although quite small, 12100 patients passed through it with 1552 major operations performed. The admissions book appears to reflect the artistic skill of some of the patients: I shudder to think of how the modern records officer equipped with suitable forms would cope with entries like these.

It is interesting to record that during 1915, before being transferred to Salonika, Mr Lester Pearson served as a medical orderly at Folkestone, and he returned on Canada Day 1970 to lay a wreath at the Canadian Cemetery at Shornecliffe. Here, in perhaps one of the most beautiful and simple cemeteries on earth, lie the bodies of nearly 1500 Canadian troops who died during the first world war, and each year since 1916 children of the local schools have tended the graves and laid flowers on them on Canada Day.

Perhaps this simple tribute carried on lovingly by children who cannot even remember the second world war, let alone the first, poses the lesson for us all. Here lie buried side by side Englishmen, Canadians, and Irishmen. Whether they fought to defend their country, whether they fought because they were professionals-or even if they just joined in the biggest fight the world had ever known-here they lie, remembered by succeeding generations who are free because of their sacrifice, evidence of the truth recalled by Wolfe on the Heights of Abraham that the "Paths of Glory lead but to the grave."

\title{
For Debate...
}

\section{Priorities: some personal views}

\author{
STEPHEN LOCK
}

British Medical fournal, 1976, 2, 1548-1551

To illustrate the difference between the Austrians and the Germans, the story is sometimes told of the two communiques their High Commands issued just before the end of the first world war. The German one read: "Situation serious, but not desperate"; the Austrian one read: "Situation desperate, but not serious." Much as I prefer rococo to baroque, Hofmansthal to Hegel, and Wiener Schnitzel to the Bauernbratwurst you get in Munich, I take the German view with regard to the present crisis in health care: it is serious but not desperate, and it can be solved even with our present resources. What's more, this crisis is apparent or imminent in most of the developed countries. Even though the richest ones such as Sweden and the United States can still afford more EMI-scanners, or more pacemakers, or more kidney transplants, we're all at the end of the road: the developments in medical technology have outstripped the money we've available to spend on health care.

I want to deal with some medical measures that have been relatively little discussed. This excludes, for example, possible social reforms, such as abolishing "poverty," however this is defined. Even today, thousands of our population are paid less than a subsistence wage, particularly those working in shops, restaurants, and hotels; yet the plight of these people has received little attention by either of the bodies who could do something about it: the major political parties or the big unions. In Victorian times some have argued that social changes,

Based on contributions given at seminars at the Royal College of Physicians of Ireland, the Royal College of General Practitioners, and the universities of Kent and Newcastle upon Tyne between October and December 1976.

British Medical Journal, London WC1

STEPHEN LOCK, MB, FRCP, editor piped water, and sewage all did more for the public health than any advances in medicine. Today, even though they might not necessarily accept that overcoming poverty would have a similar priority over medicine proper, many doctors might well argue that much of the money spent elsewhere, for example on some social workers (with their allegedly low case loads, time spent in conference, and unavailability after office hours), might more usefully be given directly to the poor. I do not know enough of the facts behind such an argument to judge.

I shall also not consider priorities which the profession seems to be on the brink of introducing for itself, such as some form of clinical self-assessment, or of encouragement of better drug prescribing habits. All professions are rightly conservative and suspicious of change until the case for it has been proved. Nevertheless, once this has been done-as in the case of the advantages of health centres, career training for specialties, or restrictions on narcotic prescribing for drug addicts-the medical profession has always been quick to withdraw any objections and, most importantly, to introduce such changes itself, rather than have them imposed from outside.

My own priorities fall into three main time scales. Firstly, immediate: action which we should take now, by applying the knowledge that we have. Secondly, intermediate: we should alter the direction of some of our research. Thirdly, long term: a determined effort to involve the public in health education and in the debate on medical priorities.

\section{Action}

SMOKING

In proposing some actions, there is one obvious and absolute priority: to do something much tougher about the greatest medical evil of our day, the cigarette. We now know of the untold harm and nuisance this addiction is causing: in Britain 